\title{
The Psychosocial Demography and Resources of Disadvantaged Children in Armed Conflict and Sustainable Community Child Protection Process: A Case Study
}

\author{
Rhodius T. Noguera
}

Received: 16 May 2014/Accepted: 15 December 2014/Published online: 15 January 2015

(C) Springer India Pvt. Ltd. 2015

\begin{abstract}
The effect of trauma from an armed conflict is central to the concern of psychosocial workers in responding to children's psychosocial needs. However, dealing with trauma is not the priority of a disadvantaged community in view of recovering from the negative impacts of armed conflict. This 2-year case study presents insights on how psychosocial workers can team-up with a community to understand people's priorities and develop indigenous child protection programs. The study emphasizes the capacity of the community to address the psychosocial concerns of children by utilizing interventions that are familiar and meaningful to them. When a community claims expertise in managing their lives by using their own strengths, this ensures a sustainable protection for children. The role of psychosocial workers is to discover the path where they can journey with a disadvantaged community.
\end{abstract}

Keywords Psychosocial demography · Psychosocial resources - Psychosocial intervention children in armed conflict - Child protection and participation - Community empowerment $\cdot$ Pintakasi

\section{Introduction}

Amidst the declaration of the United Nations on the role of humanity in protecting and promoting the welfare and rights of children, empirical studies assert that armed conflicts, propelled by the economic, territorial, cultural, ideological, and political struggles, deliver debilitating

\footnotetext{
R. T. Noguera $(\bowtie)$

Bahrain Teachers College, University of Bahrain, Manama, Bahrain

e-mail: rnoguera@uob.edu.bh
}

physical and psychosocial damages in the life of children $[2,3]$. The enduring risks of armed conflict in the life of children have attracted an increasing amount of attention in the psychological researches and psychotherapy [1]. However, there are studies that describe the limitations of the psychological interventions in addressing the complex burgeoning needs of young victim [5, 8]. Psychosocial workers need to explore the indigenous and natural coping mechanisms where children take an active role in their own healing process $[4,6]$.

In the Philippine context, psychosocial workers are usually foreign to the victims of armed conflict. The psychosocial relief efforts are dependent on the funds provided by the government and non-government agencies. When funds are exhausted, the psychosocial services are also terminated. And, nobody among the community can replicate the psychosocial interventions. Besides, paying attention to trauma is not their priority. Their paramount concerns are to rebuild their homes and livelihood and protect the children. Psychosocial rehabilitation is a necessary humanistic approach to rebuild the shattered life of the victims of armed conflict [7]. However, it is important to discover a procedure that is grounded in the sociocultural and socioeconomic priorities of the disadvantaged communities.

In search for meaningful and sustainable way to help protect the children from the harms of armed conflict, this 2-year community-based case study presents a process by which a psychologist explored a community's life. This was conducted in Sangay, a remote rural area in Southern Philippines. Prior to this study, I already stayed in Sangay for 2 years to help a community-based organization in its effort to respond to the socioeconomic and peace and order concerns. In this period, I also studied Sangay community's indigenous way of life, which is called pintakasi. This will 
be explained further in the "Results" section. Subsequently, as the politically and culturally induced peace and order situations became more problematic, I decided to focus my exploration on children's welfare in the next 2 years. Hence, by circumstantial opportunity, my previous undertaking with the community on pintakasi research led me to actualize this case study.

\section{Method}

In a nutshell, this case study was a collaboration with a community-based non-government organization, children and adult members of the Sangay community. The basic goal of this study was to discover and develop indigenous psychosocial intervention that will help protect the children from the harms brought by the armed conflict. To gather and analyze the data, I engaged in the following activities.

(a) Live in the community. To understand the actual situation of Sangay children, I lived in the community for 2 years. My entry point in the community is my connection to a non-government communitybased organization. This organization took charge of my community immersion. On the other hand, I shouldered my logistics.

(b) Understand the community. To know the community, I took an extra effort to live as if I was a member of the community by understanding their culture, language, lifestyle, needs, concerns, resources, strengths, and aspirations. I consciously opted not to be served. The community tends to treat visitors in a special way.

(c) Dialogue with the community. I tried to use the community's way of communicating. Hence, I did not introduce any new form of communicating like focus group discussion or formal interviews. With the community-based non-government organization, I clarified my role, responsibility, and relationship to the community.

(d) Collaborate with the community. I joined the community activities like farming and fishing. In partnership with the community-based non-government organization, I collaborated for the community on important concerns like the disaster management, capacity building and peace development.

(e) Validate findings to the community. I constantly asked questions to members of the community to clarify information and affirm my observations regarding a specific community concept, phenomenon, experience, or issue.

(f) Reflect with the community. There were events that I share my personal insights and experiences in the community. On the other hand, I also spent time to be alone to reflect on my experiences in the community. My background in community organizing, community psychology and child psychology helped me to deepen my reflection on the situations in the community. With my pen and paper, I discreetly recorded my reflection and observation.

To conduct a research in an armed conflict area was risky in itself. Therefore, it was important to establish a connection and positive relationship among the community leaders, respected elders, and local elected leaders. This provided somehow a sense of security in view of determining and limiting the amount of risks I was taking. On the other hand, the aspects of trust and commitment were also indispensable in this research. To deal with a fragile community necessitates clarifying personal values vis-à-vis community preferences.

\section{Results}

After 2 years of collaboration with Sangay community, I have found out that to develop a long-term psychosocial program to protect the children, I needed to consider the following elements: (a) the psychosocial demography of children, (b) the psychosocial resources of children, and (c) the indigenization of psychosocial intervention.

\section{Psychosocial Demography of Sangay Children}

The psychosocial demography is a mind map of children's psychosocial characteristics, context, and needs. This provides operational description of the day-to-day real-life conditions of children. In the case of the children of Sangay, their psychosocial demographies were centered on poverty, health care, educational, socio-political, sociocultural, ecological, and violence.

\section{Poverty}

The children's families were farmers and fishers. People would usually borrow money from traders to finance their farming and fishing activities. More often, what they produce from farming or fishing was not enough to pay for their debts. Added to this, more than $70 \%$ of the households did not own their land. The children perceived themselves as poor in the context of their food, shelter and clothes. Some children ended up as laborers.

\section{Health Care}

The health services such as free or affordable medicines and medical consultations were inadequate to cater to the 
health needs of children. There was no resident doctor or nurse. The people have limited information about preventive and emergency health care. Many homes did not have toilets.

\section{Educational}

The learning and teaching resources were scarce to provide a quality education. To reach the school, children had to walk $4-10 \mathrm{~km}$ in the mountains. More often, unaccompanied by parents, children had to cross the rivers or the sea. There were times that they had to skip classes to help their parents in farming or fishing.

\section{Socio-political}

The children were aware of the involvement of the community in governmental affairs such as abiding with government policies and rules. They had witnessed political and electoral conflicts that resulted in the death of community members.

\section{Socio-cultural}

The children were aware of their cultural affiliation that demands certain roles, responsibilities, and relationships. The children belong to either Muslim, Christian, or indigenous group. They narrated experiences of discrimination, biases and stereotyping pertaining to their cultural differences.

\section{Ecological}

The children live near the sea and in the mountains. They did not have electricity. They were aware of environmental problems related to illegal logging, fishing, mining, and managing wastes.

\section{Violence}

The children narrated stories about their actual encounters of armed conflict, ambush, massacres, and banditry. They also reported that some households kept guns for security reasons.

\section{Identify Children’ Psychosocial Resources}

The psychosocial resources are children's source of connection, protection, security, strength, and happiness. For the children of Sangay, their psychosocial resources were their dreams, family, friends, and community. Children also have their strong sense of spirituality [6] where they believe that there is a powerful being which they call "God" who will guide and protect them.

\section{Dreams}

Like any other children, Sangay children have their dreams. They said that they dream to finish college, own a big house and a car, travel places, and buy toys. They wished to have a comfortable life for their families. Some children said, "It is fine to be poor, as long as there is no war."

\section{Family}

The children narrated how they value their families. They felt protected and safe in the presence of their families. In difficult times, children stayed with their families. The family is children's source of hope, courage, and security.

\section{Friends}

The children said that they wanted to see and play with their friends. They feel happy whenever they play with their friends. I witnessed the joy of children in the evacuation centers whenever they play, eat, study, and pray together.

\section{Community}

The children showed strong attachment to the community. They witnessed how members of the community help each other in times of communal and personal needs. They were aware that they have a tradition which is called pintakasi. This is a century-old community way of life by which the farmers help each other in the entire farming activities [5]. With the scarcity of financial resources, they came up with a procedure that will help them with their farming concerns. The Pintakasi has six interconnected components: (1) maayong relasyon (positive relationship); (2) pagtinabangay (helping each other); (3) katilingbanong panginahanglan (addressing a community need); (4) kaayohan sa tanan (benefiting all); (5) walay bayad (not expecting payment); and (6) walay personal nga interes (not thinking of personal interest). To disregard one component incompletes the entire pintakasi process. As an affective procedure, the people also used pintakasi in fishing and building of church, mosques, seawalls, bridges, classrooms, and houses.

\section{Spirituality}

The children were aware of their spiritual beliefs. Specifically, they believe in a powerful being who can protect them whenever they pray. They use their respective rituals and symbols in praying during their difficult situations. They also associated spirituality in experiences related to family, community, dreams, and friends. 
Indigenization of Psychosocial Intervention

By utilizing the children's psychosocial demography and psychosocial resources, psychologists can help the community to develop a meaningful, practical, and sustainable protective intervention to address not only the aftermath of armed conflict but the eminent concerns of children. This did not involve introducing concepts and approaches like trauma healing or psychological debriefing that were unknown to the community.

For instance, I tried to reinforce the use of pintakasi in designing programs related to peace process and disaster management that promote children's welfare and protection. On the other hand, in partnership with communitybased non-government organization, the community started up with a micro-socioeconomic program to address the basic needs of children such as food and medicine. Meanwhile, the farmers and fishers reorganized themselves to come up with projects to address children's needs. Therefore, by using a procedure (pintakasi) that is well-known to the people, they strengthened the awareness in their capacity to rebuild their lives as a community. Instead of becoming a passive recipient of psychosocial relief services, the community made a conscious decision not to be helpless. This study would like to stress that without subscribing to unfamiliar procedures, the community can come up with programs by using their own organic concepts, experiences, and tested collective coping styles (pintakasi).

\section{Conclusion}

The effect of trauma from an armed conflict is central to the concern of psychosocial workers in responding to children's needs. However, this case study reports that children's concern is beyond trauma. The priority of Sangay community was not to address trauma, but to rebuild their shattered lives. Specifically, they needed food, shelter, clothes, livelihood, and security.

On the other hand, the study offers a procedure that can be meaningful and empowering to a community which is to understand the children's psychosocial demography and psychosocial resources. By understanding the unique characteristics of children, psychosocial workers can assist the community to define needs and design programs that capture their priorities, available resources, capacities, and potentials.

This study does not set aside the important role of the psychosocial experts in helping the victims of armed conflict. However, it should be noted that the presence of psychologists in the community is not permanent. The children need an intervention that is familiar to them. And, this can only be provided by children's own community. Rendering services that ignore the community's capacity and priorities may exacerbate the experience of helplessness and alienation. Whereas, helping the community to empower itself can reconnect the people to their own resources and reawaken their positive and productive experiences as a community. In effect, the community becomes the children's sensible source of healing, hope, and security. When a community claims expertise in managing their lives by using their own strengths, this ensures a sustainable protection for children. The role of psychosocial workers is to discover the path where they can journey with the community.

\section{References}

1. Bradley S, Jaycox L, Kataoka S, Rhodes H, Vestal K. Prevalence of child and adolescent exposure to community violence. Clin Child Fam Psychol Rev. 2003;6(4):247-64.

2. Catani C, Jacob N, Schauer E, Kohila M, Neuner F. Family violence, war, and natural disasters: a study of the effect of extreme stress on children's mental health in Sri Lanka. BMC Psychiatry. 2008;8:1-10.

3. Dimitry L. A systematic review on the mental health of children and adolescents in areas of armed conflict in the middle east. Child Care Health Dev. 2011;38(2):153-61.

4. Minou T. The possible models of creative therapies for the child victims of war and armed conflicts. Asia Pac Educ Rev. 2006;7(2): 229-53.

5. Noguera R. Pintakasi: when a poor community empowers itself to deal with peace and security issues, implications for the practice of psychology. Peace Stud J. 2011;4(3):16-36.

6. Noguera R. The narratives of children of armed conflict: an inference to spirituality and implication to psychological intervention. Int J Child Spiritual. 2013;18(2):162-72.

7. Peltonen K, Punamaki R. Preventive interventions among children exposed to trauma of armed conflict: a literature review. Aggress Behav. 2010;36:95-116.

8. Seely M. Psychological debriefing may not be clinically effective: implications for a humanistic approach to trauma intervention. J Humanist Couns Educ Dev. 2007;46:171-82. 